\title{
What makes restaurants successful?
}

\section{Beverly (Shih-Yun) Chen}

Beverly (Shih-Yun) started her tertiary teaching career back in 2012, and she is now a lecturer at the Auckland Institute of Studies, Auckland, New Zealand. She holds a Bachelor in International Hospitality Management (BIHM), Graduate Diploma in Tertiary Teaching, and Master of International Hospitality Management (MIHM) from Auckland University of Technology, New Zealand. She is actively involved in New Zealand's regional and national culinary competition training and judging. Her research interests include the chef industry, food and beverage industry trends, gender and careers, and private training education performance.

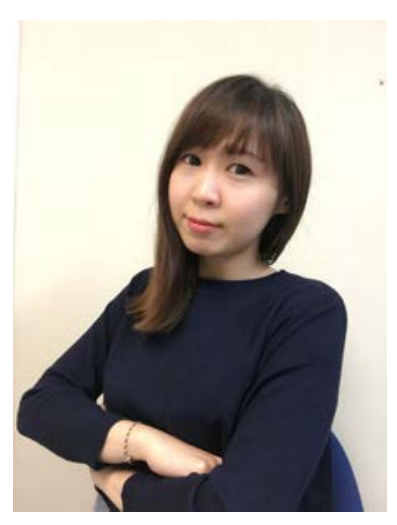

Independent restaurants face multiple challenges to their survival, including low entry barriers that create intense competition, industry norms of low pay, long working hours and a hard-working environment that can render it hard to recruit suitable employees, and a lack of support from the industry to the restaurateurs. Evidence shows that independent restaurants suffer from higher failure rates when compared to franchise restaurants [1,2]. This has been attributed to a lack of resources, especially when compared to the chained or franchised restaurants that have financial, technical and marketing support [3]. These challenges increase the failure rate for independent restaurants.

The aim of this research was to consider the notion of 'success' among Auckland's restaurateurs, and to gauge how the restaurant industry perceive their own definition of success and the main factors influencing restaurant 'success' [4]. Previous studies have predominantly measured the success of restaurant businesses by their profitable financial rewards $[5,6]$. However, this measure ignores other important aspects of restaurant operation such as the longevity of operation, customers' satisfaction levels, relationships with employees and society, and restaurateurs' own personal achievements.

The research adopted a qualitative approach involving in-depth interviews with eleven independent restaurateurs to explore the underlying factors they perceived as affecting restaurant success. A qualitative research approach helps the researcher understand people and the social and cultural contexts in which they live and work [7]. The independent restaurateurs were selected through purposeful sampling to select information-rich cases [8]. The participants were owner-operators of independent restaurants in Auckland city, and the restaurants they owned were either casual/formal-dining or styles in between.

The study findings suggested different measures of success among restaurateurs, which have implications for how the industry comes to understand and gauge business success or failure. Notably, instead of the commonly reported financial criteria, restaurateurs in this study related success to their personal achievements and satisfaction; for instance, reaching their own personal goal(s) of opening and operating a restaurant, receiving culinary related awards, and gaining media attention.

The study revealed three main factors as the important influencing factors of a restaurant's success: the operational environment; stakeholders; and management factors. 
Firstly, the operational environment of restaurants included intense competition, a constantly changing environment and changing consumer trends. In particular, the intense competition was considered to have a significant impact on the success of restaurants.

Secondly, the positive association between stakeholders and a restaurant's performance was also acknowledged. Four key stakeholders - restaurateurs, customers, suppliers and employees - were identified as influential in restaurant success. A good relationship with stakeholders was seen as beneficial to a restaurant's operation. A successful restaurant was perceived to have loyal customers, trustworthy suppliers, and employees with good skills and knowledge. Out of these stakeholders, the restaurateurs were considered the foundation of the success of restaurants, as they control the management factors. Because of this key role, restaurateurs are required to have an in-depth understanding of the restaurant industry and the ability to manage and operate the restaurant. At the same time, restaurateurs need to find a balance between their work and personal lives.

Thirdly, management factors were also felt to have an impact on independent restaurant success. This typically included decisions about the restaurant's location, purchasing and ordering, hiring and training staff, price and quality of products, and marketing and financial control.

The study provided a number of recommendations for how to successfully manage a restaurant. Firstly, thorough pre-entry research and a careful decisionmaking process will provide a good foundation for the business. Secondly, during the operation, tight financial control and effective marketing should be applied. Finally, a management system is needed in order to stay viable in the long term. A management system consisting of a standard operation manual and an extensive training programme can allow efficient restaurant operation without the restaurateur's continued presence.

In conclusion, this study found that restaurateurs in Auckland related the 'success' of their restaurants to factors other than just financial performance including personal success such as personal progression and the satisfaction gained during the operation. The operating environment, stakeholders and management factors were found to be important influences affecting restaurant success. The research recommends that a well-designed management system is vital for the long-term success of an independent restaurant business.

The full research project can be accessed here:

http://aut.researchgateway.ac.nz/handle/10292/8431

\section{Corresponding author}

Beverly (Shih-Yun) Chen can be contacted at beverlyc@ais.ac.nz

\section{References}

(1) Camillo, A. A.; Connolly, D. J.; Kim, W. G. Success and Failure in Northern California: Critical Success Factors for Independent Restaurants. Cornell Hospitality Quarterly 2008, 49(4), 364-380. https://doi.org/10.1177/1938965508317712

(2) Parsa, H. G.; Self, J. T.; Njite, D.; King, T. Why Restaurants Fail. Cornell Hotel and Restaurant Administration Quarterly 2005, 46(3), 304-322. 
(3) Parsa, H. G.; Self, J.; Sydnor-Busso, S.; Yoon, H. J. Why Restaurants Fail? Part II - The Impact of Affiliation, Location, and Size on Restaurant Failures: Results from a Survival Analysis. Journal of Foodservice Business Research 2011, 14(4), 360-379. https://doi.org/10.1080/15378020.2011.625824

(4) Chen, Shih-Y. Lessons Learned: A Qualitative Case Study of Restaurant Success in Auckland, New Zealand; Master's Thesis, Auckland University of Technology, New Zealand, 2014.

(5) Gu, Z. Analyzing Bankruptcy in the Restaurant Industry: A Multiple Discriminant Model. International Journal of Hospitality Management 2002, 21(1), 25-42. https://doi.org/10.1016/S0278-4319(01)00013-5

(6) Kim, H.; Gu, Z. Predicting Restaurant Bankruptcy: A Logit Model in Comparison with a Discriminant Model. Journal of Hospitality $\mathcal{E}$ Tourism Research 2006, 30(4), 474-493. https://doi.org/10.1177/1096348006290114

(7) Merriam, S. B. Qualitative Research: A Guide to Design and Implementation. San Francisco, CA: Jossey-Bass, 2009.

(8) Goldman, K. L. Concept Selection for Independent Restaurants. Cornell Hotel and Restaurant Administration Quarterly 1993, 34(6), 59-72. 